The Geology and Tectonic Settings of China's Mineral Deposits 
Franco Pirajno

\section{The Geology and Tectonic Settings of China's Mineral Deposits}

囪 Springer 


\section{Franco Pirajno}

Geological Survey of Western Australia

Centre for Exploration Targeting

The University of Western Australia

Perth, Western Australia

Australia

ISBN 978-94-007-4443-1

ISBN 978-94-007-4444-8 (eBook)

DOI 10.1007/978-94-007-4444-8

Springer Dordrecht Heidelberg London New York

Library of Congress Control Number: 2012938367

(C) Springer Science+Business Media Dordrecht 2013

No part of this work may be reproduced, stored in a retrieval system, or transmitted in any form or by any means, electronic, mechanical, photocopying, microfilming, recording or otherwise, without written permission from the Publisher, with the exception of any material supplied specifically for the purpose of being entered and executed on a computer system, for exclusive use by the purchaser of the work.

Printed on acid-free paper

Springer is part of Springer Science+Business Media (www.springer.com) 
献给中国人民

to the people of China 


\section{Foreword}

China is an emerging superpower, with a huge demand for raw materials and mineral resources that are being used to increase the standard of living conditions for its residents and bolster its surge forward in the global economy. To enable this rapid growth, China is also undertaking an education revolution with the help of experts from around the world in many different fields of endeavour.

This authoritative book - encyclopaedic in scope-fits very nicely into that frame by presenting a comprehensive account of China's mineral deposits and how they relate to the geological history of that vast country by one of the world's leading experts on mineral systems from Australia, Dr. Franco Pirajno.

Dr. Pirajno is eminently qualified to present this work, having had a diverse career in industry, government and academia that includes 19 years in mineral exploration with the Anglo-American Corporation of South Africa, a stint as Chair of Economic Geology at Rhodes University, South Africa, and 20 years with the Geological Survey of Western Australia. He has held visiting professorships at Peking University and China University of Geosciences and currently has honorary appointments at the Institute of Mineral Resources (Chinese Academy of Geological Sciences), Beijing, the University of Western Australia, Perth, the Centre for Russian and Central EurAsian Mineral Studies (CERCAMS, Natural History Museum, London) and the Australian Centre for Astrobiology, University of New South Wales, Sydney. This is his fourth book on mineral deposits. His first three are "Hydrothermal Mineral DepositsPrinciples and fundamental concepts for the Exploration Geologist" (Springer-Verlag 1992), "Ore Deposits and Mantle Plumes" (Kluwer Academic Publishers 2000), and "Hydrothermal processes and mineral systems" (Springer 2009).

More importantly, Dr. Pirajno has travelled extensively through China and visited a variety of that country's mineral deposits, providing the reader with first-hand accounts of critical observations.

The understated title of the book should not fool anyone: this richly illustrated and comprehensively referenced book achieves two remarkable, never previously attempted (at least in English), feats:

1) It describes and interprets the entire, 3.2 billion years, of geological history of China;

and 
2) It provides detailed accounts of a wonderfully diverse range of mineral systems and places their genesis in the context of that long and complex history.

These achievements are no mean feat, given that the People's Republic of China is the third largest country in the world, with a land area of about 9.6 million sq $\mathrm{km}$.

The book is divided into seven chapters. An introductory Chap. 1 presents historical notes on mining and geology in China, time scales and definitions used in the book. Chapter 2 provides a welcome overview of China's tectonic framework in the global context, together with tectono-thermal events that have formed the various mineral systems. This chapter provides the backdrop to the six chapters that follow, which focus on specific periods of China's geological history. Chapter 3 describes the Archaean and Palaeoproterozoic geology of the North China and Tarim cratonic blocks, including the Phanerozoic mineral systems found in these areas. In Chap. 4, the geology of the Yangtze Craton and Cathaysia are described, together with their Mesoproterozoic through Early Palaeozoic amalgamation to form the South China Block. Chapter 5 reviews the Phanerozoic South China Fold Belt, and the QinlingDabie-Sulu, Qilian and Hinggan orogens. Chapter 6 presents the geology of the Tianshan, Junggar and Altay orogenic belts in northwest China (Xinjiang), part of the huge Central Asian Orogenic Belt that extends from the Uralides in the west to the Pacific Ocean margin of eastern Asia. The Alpine-Himalayan fold belts (Tethyan orogens), and Kunlun and Songpan-Ganzi terranes are also described in this chapter. Chapter 7 is devoted to an overview of the Large Igneous Provinces (LIPs) of China, which range in age from Paleoproterozoic through to the Jurassic, and the widespread Yanshanian (Mesozoic) tectono-thermal event. Lastly, Chap. 8 describes the volcano-sedimentary and sedimentary basins and grabens that cover much of China and are important due to their hydrocarbon resources.

However, the real strength of the book lies in the diversity of mineral systems investigated and the detailed descriptions of their occurrence, including well-known volcanogenic massive sulphide (VMS) deposits, epithermal and orogenic lode $\mathrm{Au}-\mathrm{Ag}$ deposits, and orthomagmatic $\mathrm{Ni}-\mathrm{Cu}$ and porphyry-style mineralisation, to less well known rare earth element (REE) deposits, $\mathrm{Cu}-\mathrm{Fe}-\mathrm{Au}$ skarns, rare metal pegmatites, and phosphorite and uranium deposits.

In summary, The Geology and Tectonic Setting of China's Mineral Deposits by Dr. Franco Pirajno represents a remarkable contribution in the understanding of China's rich and diverse mineral resource that will significantly enhance the success of commodity exploration in that country and its ability to sustain its growth well into the future.

Martin J. Van Kranendonk Professor of Geology University of New South Wales Sydney, Australia 


\section{Foreword}

The study of ore genesis is to understand how different mineral commodities, essential for the well-being of human beings, were formed. Such studies serve two purposes. First, they help to satisfy our curiosities about the world we live in. More practically, a good understanding of how the various mineral deposits were formed gives us the predictive power of defining where to look for new deposits.

I was almost totally ignorant about ore genesis during the early days of my career, partly because of my lack of opportunity to learn about it, partly because I was scared by the jargon such as VMS, MVT, SEDEX etc. Later on through my tectonic work in Jiaodong, eastern China where about a quarter of China's gold production comes from, and through running a research project on the tectonic evolution and iron ore genesis in the Hamersley Province of the southern Pilbara craton in Western Australia, of course also through attending talks by people working in the field, I gradually learnt that ore genesis is just part of the geological process that most of us can relate our research to. In other words, mineral deposits are no more than rocks (or sands in the case of mineral sand deposits) with special concentration of certain minerals or elements that are of economical value to society.

Economic geology is no doubt a field that requires specific knowledge, and has some unique approaches in conducting research. There are many excellent studies which approach ore genesis from the angle of Earth processes, linking mineralisation systems to broader geotectonic processes and events. Nonetheless, I noticed that there are also many studies that appear to stop at classifying mineral deposits into certain known categories, thus producing little new understanding about ore genesis and limiting the potential of having real predictive power of such studies to mineral exploration.

The Chinese continental crust is a mosaic of small cratons or terranes that had diverse origins, complex amalgamation histories, and often multiple postamalgamation modifications. As such, it exhibits a full range of geotectonic environments and provinces fertile for a wide spectrum of mineral deposits. To fully understand the genesis of major mineralisation systems, be it related to continental rifting, mantle plume events, subduction systems, continental collision, terrane accretion, delamination, etc. etc., it is important to examine such mineralisation systems (not just individual deposits) in the context of the regional geotectonic 
environments. Much excellent work has been done in the past, dominantly by Chinese researchers on Chinese ore genesis. A good such example is the study of the V-FeTi-PGE and Ni-Cu-PGE deposits related to the Permian Emeishan mantle plume event. Nonetheless, because of the complex tectonic histories experienced by the Chinese continental blocks and orogenic belts, either between these blocks or within individual blocks, our past understanding of many of the mineral systems has been hampered by our limited knowledge of the tectonic evolution of the region, such as the nature of each major orogenic or magmatic event and how such events influenced the major mineralisation systems and provinces.

All these started to change rapidly in the past decade or so, thanks to the wide availability of modern analytical tools such as LA-ICPMS and SIMS among others, and the introduction of modern research approaches and scientific concepts into the Chinese geoscience community. For instance, we are now able to link discrete gold mineralisation events in Jiaodong to precisely dated tectono-thermal events; we can now link the major pulses of magmatic events and related mineralisation systems in south China to possible plume events, orogenic collapses, slab delamination events, and so on. Nonetheless, this renaissance of geoscience research in China has only just started, with many new hypotheses still hotly debated, and many orogenic and magmatic events still poorly understood.

It is from this point of view that Professor Franco Pirajno's new book on "Geology and tectonic settings of China's mineral deposits" is very timely. Franco has a distinguished scientific career specialising on tectonics and mineral systems in Africa, Australia and many other parts of the world. He previously published three books on tectonics and mineral deposits: Hydrothermal Mineral Deposits (Springer-Verlag 1992), Ore Deposits and Mantle Plumes (Kluwer Academic Publishers 2000) and Hydrothermal Processes and Mineral Systems (Springer 2009). His interest turned to China about 15 years ago, leading to many high-impact scientific papers with Chinese colleagues. In the current book, he offers his views, as a western-based researcher, on Chinese tectonics and mineral deposits.

Following an Introduction (Chap. 1), the book is structured in such a way that readers will first get a general picture of the tectonic evolution of the Chinese continent in general (Chap. 2), and that of particular cratons or orogenic belts concerned by each chapter (Chaps. 3 to 6), followed by detailed accounts of all major mineral deposits in geological province concerned. Large Igneous Provinces in China are given special emphasis in a standalone Chap. 7, whereas Chap. 8 is devoted to volcanosedimentary basins. In such a way individual deposits are no longer being treated in isolation. Instead, they are all part of various mineral systems/provinces lined to particular tectonic events.

During his years of interactions with China-based researchers, Franco has visited many parts of China and numerous deposits. The personal insights gained during such close collaborations are no doubt reflected in the many chapters. Of course, any book of such comprehensive nature would unavoidably involve much literature review and data compilation, including traditional views. In some instances Franco's preferred interpretations differ from mine, but this merely reflects the rapidly evolving nature of our understanding of the region. 
This book will thus serve as an invaluable starting point for researchers from both outside and inside China to gain a general knowledge of a specific region or mineral commodity that they are interested in. I look forward to having a printed copy in hand.

Prof. Zheng-Xiang Li Palaeomagnetism and Tectonics Department of Applied Geology Curtin University of Technology, Perth, Western Australia 


\section{Acknowledgements}

I consider myself lucky to be part of a "sans frontierès" geoscience community, which has allowed me to visit and study numerous geological sites and mineral deposits and to share ideas and knowledge with colleagues from China, Australia, New Zealand, Russia, the United Kingdom, South Africa, Kyrgystan, the USA and Canada. They have all been a source of inspiration. Since my early visits and field experiences in China, I witnessed over the years, what can be labelled as an unprecedented surge and achievements by the Chinese in scientific, social and humanistic endeavours, perhaps never before experienced in the history of humanity .

In the writing of this book, I thank the reviewers who have taken precious time to read a selection of chapters: Remair Seltmann (Chap. 1), Nacho González-Álvarez (Chap. 3), Hugo de Boorder (Chap. 4), Peng Peng (Chap. 6) and Leon Bagas (Chap. 7). Rick Rogerson and Don Flint of the Geological Survey of Western Australia (GSWA) are thanked for their understanding (mostly behind the scenes) to let me wander and allowing time to write this book and to use the GSWA technical resources. Murray Jones, Michael Prause, Dellys Sutton and Joyce Peng (all at GSWA) drafted the figures, and gave their time even when under pressure for other jobs. Nell Stoyanoff (GSWA secretary) typed most of the tables. Librarians Brian Knyn and Eunice Cheung are thanked for never failing in their help in tracking down papers and books. I extend my gratitude to my Chinese friends and colleagues for their hospitality and generous support in numerous field trips in China, in no special order they include: Mao Jingwen (Institute of Mineral Resources, Chinese Academy of Geological Sciences), Chen Yanjing (Peking University), Zhou Taofa (Hefei University of Technology), Zhang Shihong, Han Higuy and Cheng Yanbo (China University of Geosciences, Beijing), Xiao Long (China University of Geosciences, Wuhan), Zhang Lianchang, Xiao Wenjiao, Peng Peng and Wu Huaying (Chinese Academy of Sciences, Beijing).

I take full responsibility for the contents of this book. If I have misrepresented some of the concepts or ideas obtained from the literature, this was unintentional and in no way reflects a disregard for the original author(s)' work.

Last, but not least, I thank my wife and lifelong companion for not giving up on me. 


\section{Contents}

1 Introduction $\ldots \ldots \ldots \ldots \ldots \ldots \ldots \ldots \ldots \ldots \ldots \ldots \ldots \ldots \ldots \ldots \ldots \ldots, 1$

1.1 Introductory Statement and Overview of Mineral Resources

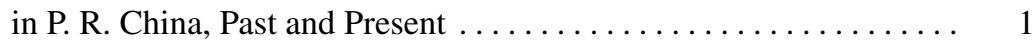

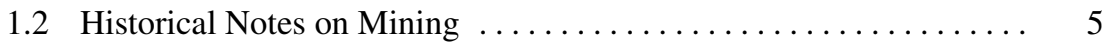

1.3 Historical Notes on Geology in China . . . . . . . . . . . . . . 7

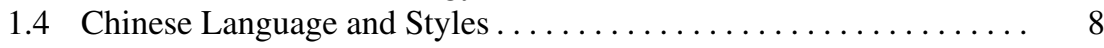

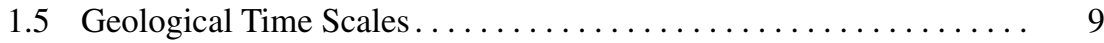

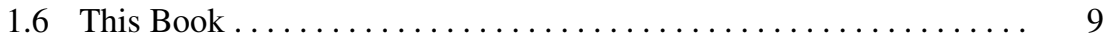

1.7 Some Useful Definitions Used in this Book . . . . . . . . . . 15

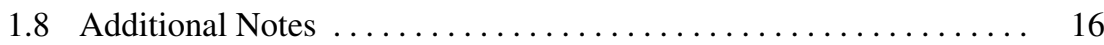

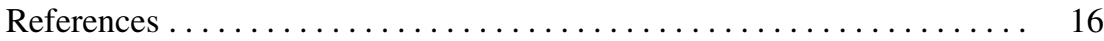

2 China's Tectonic Framework in the Global Context . . . . . . . . . . . . 19

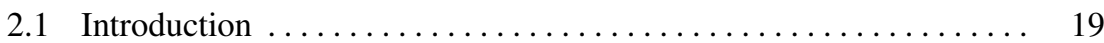

2.2 Outline of the Tectonic Framework and Geodynamic Evolution of China and Its Mineral Systems ................... 24

2.3 Volcano-sedimentary and Sedimentary Basins . . . . . . . . . 30

2.4 Concluding Remarks ......................... 31

References ................................ 32

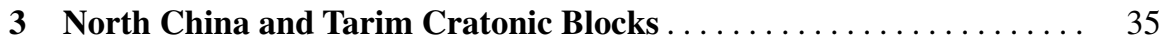

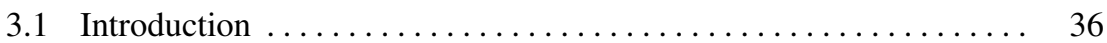

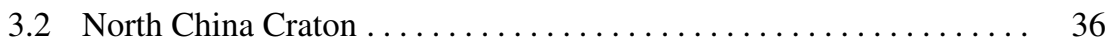

3.2.1 Eastern and Western Blocks.................... 38

3.2.2 Trans-North China Orogen $\ldots \ldots \ldots \ldots \ldots \ldots \ldots \ldots \ldots . \ldots \ldots$

3.2.3 Palaeoproterozoic Fold Belts and Rifting in the NCC . . . . 47

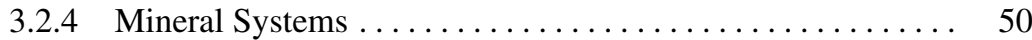

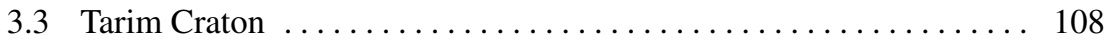

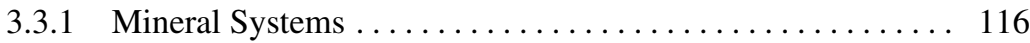

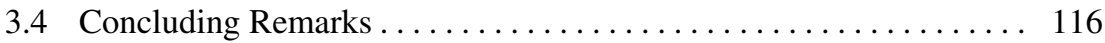

References ............................... 118 
4 Yangtze Craton, Cathaysia and the South China Block . . . . . . . . . 127

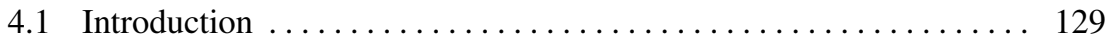

4.2 Yangtze Craton . . . . . . . . . . . . . . . . . . . . . . . 132

4.2.1 Archaean and Proterozoic Lithostratigraphy .......... 133

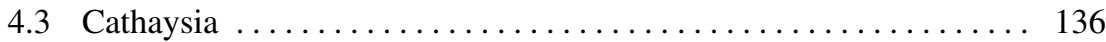

4.4 Mineral Systems of the Yangtze Craton and Cathaysia . . . . . . . . . 139

4.4.1 Stratabound and/or Stratiform Massive Sulphides Deposits . 140

4.4 .2 MVT Deposits ........................ 162

4.4.3 Carlin-style Au Deposits ................... 164

4.4.4 Porphyry and Quartz-vein W Ore Systems . . . . . . . . . 171

4.4.5 The Middle-lower Yangtze River Valley Metallogenic

Province .......................... 181

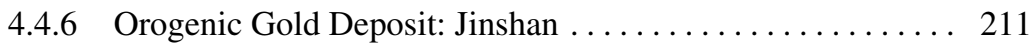

4.4.7 Gejiu Sn-Cu District, SW Cathaysia................. 213

4.4.8 Metalliferous Black Shales in the Yangtze Platform .... . . . 217

4.5 South China; Basins in Cathaysia and Uranium Mineralisation . . . . . 222

4.5.1 Granite-related U Ore Fields . . . . . . . . . . . . . . . . . . 225

4.5.2 Volcanic-related U Ore Fields .................. 231

4.6 REE, Nb, Ga (Rare Metal) Mineralisation in a Coal-bearing

Sedimentary Succession ..................... 234

4.7 Shilu Fe (Cu-Co) Deposit (Hainan Province); A Polygenetic

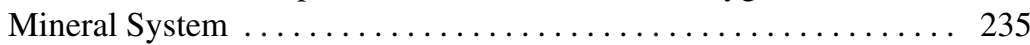

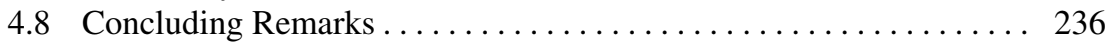

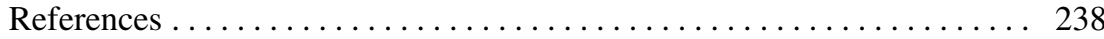

\section{Orogenic belts: South China, Central China}

and Qinling-Dabie, Hinggan . . . . . . . . . . . . . . . . . . . . 249

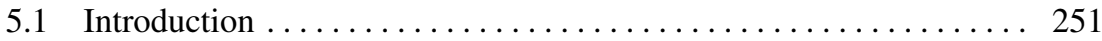

5.2 South China Fold Belt ....................... 251

5.2.1 Zhilingtou and Huangshan Epithermal Systems,

Chencai-Suichang Uplift, Zhejiang Province ......... 257

5.2.2 Fujian Province's Epithermal-porphyry Systems . . . . . . . 260

5.2.3 Mineralisation in the Coastal Volcanic Belt ........... 262

5.2.4 Chinkuashih Epithermal Systems in Taiwan .......... 266

5.3 Qinling-Dabie-SuLu Orogenic Belt . . . . . . . . . . . . . . . . 267

5.3.1 Mesozoic Granitic Magmatism ................... 271

5.3.2 Geodynamic Evolution Model for the Qinling-Dabie

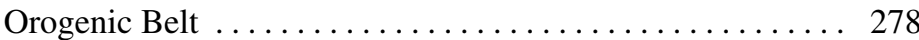

5.3.3 Mineral Systems of the Qinling-Dabie Orogenic Belt . . . . . 282

5.4 Hinggan (Hing'an, Xing'an) Orogenic Belt, Northeast China . . . . . 331

5.4.1 Indosinian and Yanshanian Magmatism . . . . . . . . . 338

5.4 .2 Hydrothermal Mineral Systems.................. 339

5.4 .3 Magmatic Mineral Systems . . . . . . . . . . . . . 362

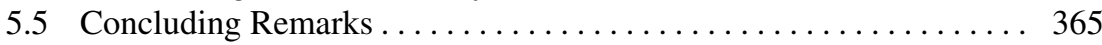

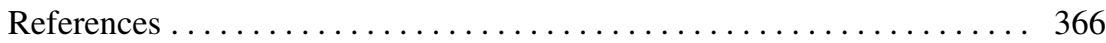


6 Tianshan, Junggar and Altay Orogens (NW China), the Alpine-Himalayan Fold Belts (Tethyan Orogens),

Kunlun and Songpan-Ganzi Terranes $\ldots \ldots \ldots \ldots \ldots \ldots \ldots$

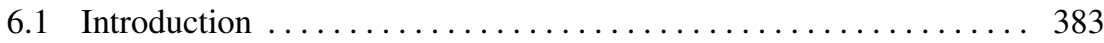

6.2 Central Asian Orogenic Belt; Tianshan and Altay Orogenic

Belts in Northern Xinjiang (NW China) . . . . . . . . . . . . . . . . 384

6.2 .1 Tianshan and Yili Block . . . . . . . . . . . . . . . . 387

6.2.2 Altay (Altai) Orogen. . . . . . . . . . . . . . . . . . . . . . . . . . . 397

6.2.3 West- and East Junggar Fold Belts . . . . . . . . . . . . . 400

6.3 Mineral Systems of Tianshan, and Altay Orogens and Yili Block

in NW China .............................. 403

6.3 .1 Porphyry Systems . . . . . . . . . . . . . . . . . . 405

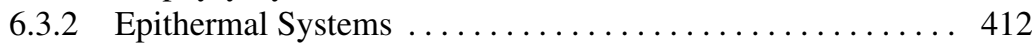

6.3 .3 Gold Lodes $\ldots \ldots \ldots \ldots \ldots \ldots \ldots \ldots \ldots \ldots \ldots \ldots \ldots \ldots . \ldots \ldots 4$

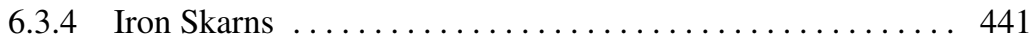

6.3.5 Volcanogenic Massive Sulphides (VMS) . . . . . . . . . 452

6.3.6 Magmatic Ni-Cu-(PGE) and Ophiolite-hosted Cr Deposits . 457

6.3.7 Sandstone-hosted (roll-front) Uranium. . . . . . . . . . . . . . 467

6.3.8 Rare Metal Pegmatites ..................... 470

6.4 Alpine-Himalayan Orogenic Belts (Tethysides) . . . . . . . . . . . 474

6.4.1 Mineral Systems; Overview . . . . . . . . . . . . . . . . . . 483

6.5 Kunlun and Songpan-Ganzi Terranes ................ 521

6.5.1 Kunlun Terranes and Qaidam Terrane ............ 522

6.5 .2 Songpan-Ganzi ...................... 524

6.5.3 Mineral Systems in Kunlun and Songpan-Ganzi Terranes . . 525

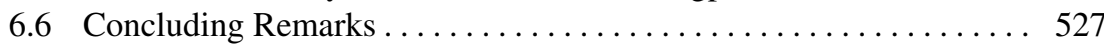

References .............................. 530

7 Large Igneous Provinces (Xiong'er, Dashigou, 827 Ma Event, Tarim, Emeishan) and the Yanshanian Tectono-thermal

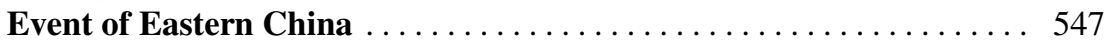

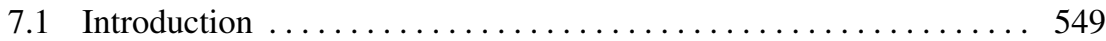

7.2 The Xiong'er Volcanic Province and Coeval Dyke Swarms in the

Central North China Craton: A 1.78 Ga Large Igneous Province . . . 552

7.2.1 Tectonic Setting and the Mantle Plume Debate .......... 556

7.3 A Newly Discovered LIP: ca. 925 Ma Dashigou Dyke Swarm in the North China Craton: Implications for Mineral Deposit Targeting . . 561

$7.4850-825$ Ma Event and the Rodinia Connection ............ 563

7.4.1 Mineral Systems . . . . . . . . . . . . . . . . . . . . . . 565

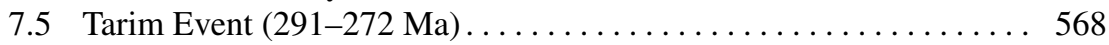

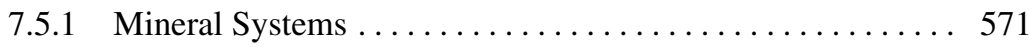

7.6 Emeishan Large Igneous Province . . . . . . . . . . . . . . 576

7.6.1 The Emeishan Mantle Plume.................... 580

7.6 .2 Mineral Systems . . . . . . . . . . . . . . . 581 
7.7 The Yanshanian Tectono-thermal Events in Eastern China . . . . . . . . 604

7.7.1 Mechanisms of Lithosphere Thinning and Mantle

Dynamics Under Eastern China ............... 611

7.7.2 Great Hinggan (Xing'an) Range: A Yanshanian Giant

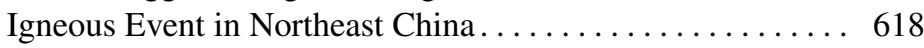

7.7 .3 Mineral Systems . . . . . . . . . . . . . . . . 622

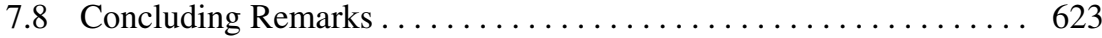

References .................................. 625

8 Volcano-sedimentary and Sedimentary Basins in China: Junggar,

Tarim, Tuha, Qaidam-Hoh Xil, Ordos; Basins in Eastern China

Associated with Lithospheric Thinning (Songliao, Bohai) . . . . . . . . . 639

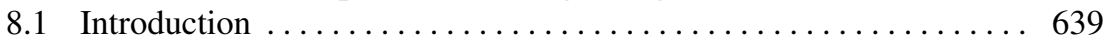

8.2 Junggar Basin . . . . . . . . . . . . . . . . . . . . . . . . . . . . 644

8.2.1 Mineral Systems . . . . . . . . . . . . . . . . . . . . . . . . . 646

8.3 Tuha (Turpan-Hami) . . . . . . . . . . . . . . . . . . . . . . 646

8.3 .1 Mineral Systems . . . . . . . . . . . . . . . . . 647

8.4 Tarim Basin . . . . . . . . . . . . . . . . . . . . . . . 647

8.5 Qaidam and Hoh Xil Basins . . . . . . . . . . . . . . . . . . 651

8.6 Ordos Basin . . . . . . . . . . . . . . . . . . . . . . 654

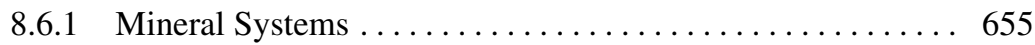

8.7 Songliao and Bohai Volcano-sedimentary Basins . . . . . . . . . 657

8.7.1 Songliao Volcano-sedimentary Basin . . . . . . . . . . . . 659

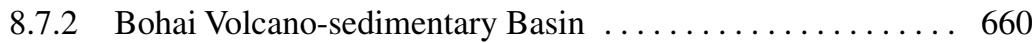

8.7 .3 Mineral Systems . . . . . . . . . . . . . . . . . . . . . . . . . 662

8.8 Concluding Remarks . . . . . . . . . . . . . . . . . . . . . . . . 662

References ................................. 664

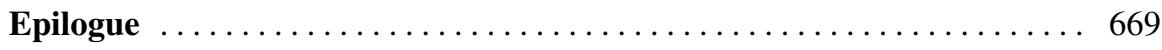

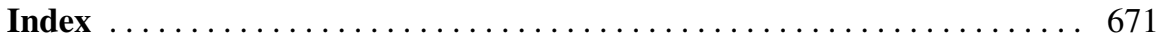

